longest surviving of them all. Neither he nor any of his brothers were married; one sister was, but she left no brothers were marrier, in I793. Between 1803 and 1808 he was a pupil at the High School, Edinburgh, after leaving which he entered the University of that city as a medical student, attending the lectures of Drs. Monro, Hope, Gregory, Duncan, and others. He took his doctor's degree in I8I4, for five years after which he devoted his time to travelling on the Continent, visiting Paris, Rome, Florence, as well as Germany, Bohemia, Hungary, and Austria. In 1822 he settled in Edinburgh, and from then till 1828 contributed several zoological papers to different Scot scientific societies and journals, including one to the Wernerian Natural History Society, in 1827 , on the circulation of fluids through the structure of sponges, in which attention was first drawn to the function of the ossicula and pores of those animals, and which led Mr. Fleming to give the generic name Grantia to one member of the family.

In June 1827 , whilst still in Edinburgh, Dr. Grant was elected Professor of Zoology and Comparative Anatomy in the new University of London, then being formed; his first lecture was not however delivered until October 1828 . For the first few years after he settled in London he communicated several papers on zoological subjects to the Scientific Committee of the Zoological Society, some of which, on points in the anatomy of Sepiola, Loligopsis, and Beroë, read in 1833 , are to be found in the first volume of their Transactions. From that time Dr. Grant published no papers of importance.

In I 836 Dr. Grant was elected a Fellow of the Royal Society, and in 1837 he was appointed to the triennial Fullerian Professorship of Physiology at the Royal Institution in Albemarle Street.

At his classes, during one session, it is said that Dr. Grant had only two attendants, these being Mr. Hallam, the illustrious historian, and a young boy; it was always a matter of surprise to the other students of the college how he managed to adapt his lectures to the mental capacity of this trying audience.

During the forty-six years that he held his professorship, he never missed a single lecture. It was his determination, if he had lived, to resign his appointment during the present year.

In disposition Dr. Grant was very retiring and seclusive, and a great reader. He travelled much and was an excellent linguist ; so fond of languages was he, that only two years ago he attended lectures on Anglo-Saxon in University College. By his will Dr. Grant leaves his extensive library and all his private collection to University College, together with a sum of money to be employed in maintaining and extending the zoological and zootomical department of the library of the college.

\section{CONFERENCE FOR MARITIME METEOROLOGY}

A GENERAL wish having of late been expressed that the measures for the prosecution of Maritime Meteorology, proposed at the International Conference at Brussels in 1853 , should be reconsidered, now that the experience of more than twenty years of the operation of these measures has enabled meteorologists to form opinions as to their utility, a conference is now being held at the Meteorological Office, II6, Victoria-street, consisting of the following gentlemen :-Austria-R. Müller, K. K. Hydrographic Office, Pola. *BelgiumVan Rysselberghe, Navigation School, Ostend. BengalH. F. Blanford, Meteorological Office, Calcutta. ChinaJ. D. Campbell, Secretary Commissioners of Maritime Customs. Denmark-Capt. N. Hoffmeyer, Meteorological Institute, Copenhagen. France-C. Sainte-Claire Deville, Inspector of Meteorological Stations; A. Dela- marche, Ministry of Marine, Paris. Germany-W. H. von Freeden, Deutsche Seewarte, Hamburg ; G. Neumayer, Hydrographer, Berlin ; Capt. Stempel, Imperial Navy; H. A. Meyer, Commissioner for Investigating German Seas, Kiel. Great Britain---(Board of Trade), Capt. Toynbee; R. H. Scott, Director Meteorological Office, Hon. Sec. ; *(Admiralty), Rear-Admiral Nolloth ; R. J. Mann, M.D., President Meteorological Society. Holland -Buys Ballot, Royal Meteorological Institute, Utrecht, President; Lieut. J. E. Cornelissen, R.N. Italy - Capt. N. Canevaro, R.N. Norway-H. Mohn, Meteorological Institute, Christiana. Portugal-J. C. de Brito Capello, Observatory, Lisbon. Russia-Capt. M. Rikatcheff, I.R.N., Central Physical Observatory, St. Petersburg; *A. Movitz, Observatory, Tiflis. Spain-C. Pujazon, Marine Observatory, San Fernando; Captain Montijo, S.N. *Turkey-Admiral Hobart Pacha. The basis of discussion will be the Report of the Brussels Conference above referred to, with some other heads relating to instructions, instruments, \&c. The Conference will be divided into two sub-committees:- I. Instruments ; 2 . Observations. A Report of the proceedings will be published by the Meteorological Committee. A programme has already appeared in NATURE, vol. x. p. 152 .

\section{DEEP-SEA SOUNDINGS IN THE PACIFIC OCEAN}

$W^{\mathrm{E}}$ take the following extracts on this subject from a report made to the United States Secretary of the Navy by Commander George E. Belknap, dated United States Steamer Tuscarora, Hakodadi, Japan, June 26 :-

"I left Yokohama on the 8th inst., and at dawn the next morning began the work of sounding homeward on a great circle passing through the island of Tawaga, of the Aleutian group, and towards Puget's Sound. When about 100 miles east by south from Kinghasan or Sendai Bay, on the east coast of Japan, the lead sank to a depth of 3,427 fathoms, showing a descent of 1,594 fathoms in a run of 30 miles. The result seems extraordinary at so short a distance from the land, but the next coast revealed a depth still more astonishing, the sinker carrying the wire down 4,643 fathoms without reaching the bottom.

"On this occasion, when some 500 fathoms of wire had run out, the sinker was suddenly swept under the ship's bottom by the strong undercurrent, and all efforts to get the wire clear and keep it from tending underneath were unavailing, the difficulty being increased by a fresh breeze and a moderately heavy sea. Finally, when 4,643 fathoms of wire had run out, and only 150 fathoms of wire were left on the reel, it broke close to the surface, and about five miles were lost.

"The strain on the reel was very great, and notwithstanding a weight of $\mathrm{r} 30 \mathrm{lb}$. on the pulley. line, it took three men to check and hold the drum, and the wonder was that the wire had not parted sooner. This great strain must have been due to the action of the strong undercurrent upon the sinker, sweeping it with great force from the ship, as since that cast we have sounded repeatedly in depths of more than 4,000 fathoms, and had no trouble in reaching the bottom.

"The position of the cast, as shown by observation was about 45 miles distant from the previous one, the strong current having carried the ship beyond the position where it was intended to sound. . . . .

"I determined to run back inshore and skirt the stream, beginning a new great circle off Point Komoto, in latitude $40^{\circ}$ north. I also concluded to increase the weight of the sinker some $20 \mathrm{lb}$. ....

"It will be seen, by an inspection of the track chart of sounding, that the moment the second line diverges from the coast of Niphon and enters the edge of the Japan

* Not present at the meeting on Aug. $3 \mathrm{r}$. 